\title{
KINERJA THERMOELECTRIC PADA KOTAK PENDINGIN BERDASARKAN RANGKAIAN THERMOELECTRIC DAN PUTARAN FAN WIND TUNNEL
}

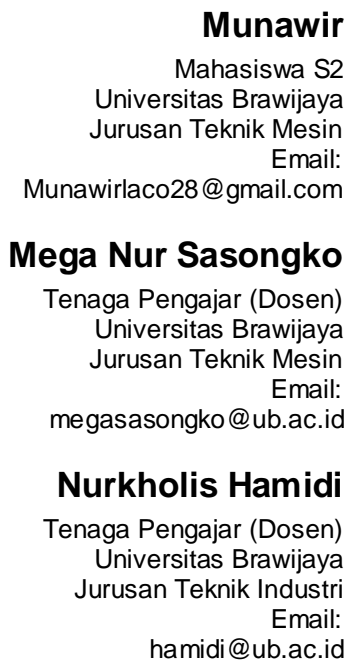

Munawir Universitas Brawijaya Mesin El.com
Mega Nur Sasongko aga Pengajar (Dosen) Universitas Brawijaya Email: megasasongko@ub.ac.id
Nurkholis Hamidi naga Pengajar (Dosen) Universitas Brawijaya Email: hamidi@ub.ac.id

A thermoelectric cooler (TEC) is a component of an electric solidstate cooler that works as a heat pump in the cooling process. Utilizing the peltier effect that is when an electric current is flowed heat absorption occurs on both sides of the thermoelectric and the release of heat on the other side. The use of thermoelectric as a coolant in cool box systems has been widely studied. The purpose of this study was to determine the performance of the cooler using thermoelectric based on the circuit and air velocity in the wind tunnel. The studied performance includes temperature difference, heat absorption, and coefficient of performance. The method used in this study is a real experimental method, with research variables namely series and parallel thermoelectric series and wind tunnel air velocity. Data were taken in the form of cool room temperature cold side temperature, hot side temperature, heatsink temperature, and ambient temperature. Thermoelectric connectivity electrically uses series and parallel circuits and is thermally arranged in series. The results showed that the thermoelectric circuit and wind tunnel air velocity affect the performance of the thermoelectric. Thermoelectric with series circuit produces the highest COP absorption compared to the parallel circuit. The highest performance thermoelectric series is obtained at an airspeed of $9.8 \mathrm{~m} / \mathrm{s}$. in these conditions the temperature difference (AT) produced reaches $19^{\circ} \mathrm{C}$. the heat absorption $\left(q_{c}\right)$ reaches 34.26 watts and the COP reaches 0.89 .

Keywords: Cooler Box, Thermoelectric Module, Series Circuit, Parallel Circuit, $C O P$

\section{PENDAHULUAN}

Kebutuhan terhadap teknologi semakin berkembang pesat salah satunya yaitu alat pendingin seperti kulkas yang mempunyai fungsi untuk mengawetkan maupun menyegarkan makanan dan minuman. Namun kulkas konvensional memiliki ukuran yang besar, membutuhkan daya yang besar. Selain itu, sebagian besar kulkas konvensional mengandung Chloro Flouro Carbon (CFC). Jika CFC terlepas ke udara maka akan berdampak pada lapisan ozon semakin menipis. Hal ini disebabkan adanya radiasi matahari atau terperangkapnya panas matahari oleh gas Chloro Flouro Carbon [1]. Mempercepat pemanasan global maka perlu adanya mesin pendingin yang tidak menggunakan $\mathrm{CFC}$, diantaranya mesin pendingin yang menggunakan thermoelektric. Pendingin thermoelektric lebih unggul dibandingkan dengan mesin pendingin konvensional yang menggunakan kompresi uap. Keunggulannya adalah tahan lama, mudah dioperasikan, kompak, ringan dan perawatan mudah [2]. Disamping itu, juga dapat mengurangi penggunaan listrik untuk menghasilkan efek pendinginan dan juga memenuhi tantangan energi saat ini. Selain itu, pendingin thermoelektric memiliki kelemahan yaitu tidak cocok untuk mesin pendingin berkapasitas besar, dan coefficient of performance masih sangat rendah [3]. Kinerja thermoelektric dengan variasi daya input dan beban pendinginan. Daya input tinggi COP semakin rendah, semakin besar beban pendinginan semakin lama stabilitas suhu kotak pendingin dapat tercapai [4].

Kinerja thermoelektric beberapa variasi posisi thermoelektric dengan menggunakan box pendingin ukuran $215 \mathrm{~mm}$ X $175 \mathrm{~mm}$ X $130 \mathrm{~mm}$ ketebalan dinding box $50 \mathrm{~mm}$. Posisi thermoelektric berada dibawah, diatas dan di dinding. Dengan demikian, diperoleh COP menurun terhadap waktu dan posisi terbaik penempatan thermoelektric adalah di dinding [5]. Kinerja kotak pendingin menggunakan 2 unit pembuang 
panas yaitu single fan heat pipe (SFHP) dan heat sink fin-fan (HSFF), single fan heat pipe memiliki coefficient of performance yang lebih tinggi dibandingkan heat sink fin-fan [6].

Perbedaan jumlah (2 dan 3) modul pendingin thermoelektric pada kotak pendingin minuman. Penggunaan 3 modul thermoelektric cooling dengan penambahan fan dan aluminium blok memiliki COP dan daya serap kalor yang lebih tinggi dengan temperatur mencapai $14,3{ }^{\circ} \mathrm{C}$ [7]. Peningkatan laju aliran fluida pendingin pada heat sink berefek pada peningkatan laju lepasan kalor pada sisi panas dan arus listrik TEC yang diikuti dengan penurunan temperatur sisi dingin TEC. Laju serapan kalor pada sisi dingin TEC yang relatif konstan menyebabkan COP sistem mengalami penurunan seiring dengan peningkatan laju aliran fluida pendingin [8]. Kemampuan elemen peltier dalam melakukan proses pendinginan tergantung pada jenis transfer panasnya, transfer panas dengan memamfaatkan satu elemen peltier dengan heatsink dan fan lebih baik daripada menggunakan pompa dua elemen peltier [9]. Tegangan yang semakin tinggi pada sistem pendingin mengakibatkan muka suhu ruang peti, heat pipe dan heat sink semakin rendah [10]. Penyusunan dan jumlah elemen peltier TEC alat transportasi ikan segar menggunakan 2 buah TEC dan 4 buah TEC yang disusun secara tunggal dan 2 buat TEC yang disusun secara ganda. Dengan demikian, COP yang tertinggi terjadi pada 2 buah elemen yang disusun secara ganda. Hal ini disebabkan daya input berbanding lurus terhadap daya serap kalor [11]. Pengunaan 1 cascade yang aktif pada thermoelektric cooling pada box portable diperoleh kinerja performance yang lebih tinggi daripada penggunaan 2 cascade dan 3 cascade [12].

Beberapa hasil penelitian diatas terlihat bahwa hanya mengamati kinerja dari thermoelektric berdasarkan jumlah modul thermolektrik yang digunakan, posisi dari thermoelektric itu sendiri dan bagaimana pengoperasian thermoelektric. Namun belum diamati bagaimana kinerja dari thermolektrik berdasarkan rangkaian thermoelektric dan kecepatan pembuangan kalornya. Rangkaian thermoelektric sangatlah penting dilakukan karena sebuah rangkaian membawa pengaruh yang signifikan dan membuat sebuah konstruksi bagaimana kalor lebih cepat diserap dan capaian temperatur ruang lebih rendah. Oleh karena itu tujuan dalam penelitian ini adalah untuk mengetahui bagaimana kinerja (beda temperatur, kalor yang diserap, dan $\mathrm{COP}$ ) dari pendinginan menggunakan thermoelektric berdasarkan rangkaian dan kecepatan putaran fan wind tunnel

\section{METODE DAN BAHAN}

\subsection{Alat dan Bahan}

Penelitian ini menggunakan metode eksperimental. Alat penelitian yang digunakan terdiri dari kotak Styrofoam dengan ukuran $310 \times 190 \times 240 \mathrm{~mm}$ dengan ketebalan $30 \mathrm{~mm}$. Modul thermoelectric yang digunakan adalah type TEC1 12706 dengan ukuran $40 \times 40 \times 3.8 \mathrm{~mm}$ memiliki daya maksimum 9,2 watt seperti pada Gambar 1.

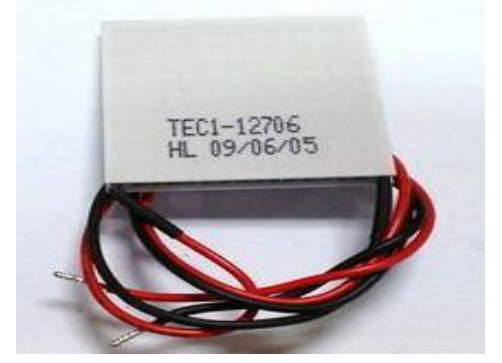

Gambar 1: Modul thermoelektric

Penggunaan termokopel sebagai sensor untuk mengukur temperatur udara, adapun jenis termokopel yang digunakan adalah termokopel jenis tipe $\mathrm{K}$ dengan range pengukuran -100 hingga $1250{ }^{\circ} \mathrm{C}$. Selain itu, alat pembaca variabel yang diukur adalah data logger jenis DAQNavi_SDK, daya sebesar 5V@60mA;Max5V@400mA dan input range 5 - 30 V DC. Untuk mengukur arus listrik, tegangan dan hambatan listrik menuju modul thermoelektric menggunakan multimeter.

\subsection{Instalasi Penelitian}

Instalasi pengujian yang dilakukan pada penelitian ini ditunjukkan pada Gambar 2. Kotak styrofoam, thermoelektric, heatsink dan kipas dirangkai menjadi kotak pendingin yang utuh. Pada bagian dalam kotak styrofoam dipasang coolsink dan termokopel untuk mengukur temperatur ruang kotak pendingin. Antara coolsink dan heatsink dipasang modul thermoelektric. Temperatur sisi dingin modul thermoelektric diukur dengan menggunakan termokopel kedua yang dipasang antara sisi dingin modul dan coolsink. Temperatur sisi panas modul thermoelektric diukur menggunakan termokopel ketiga yang dipasang antara sisi panas modul dan heatsink. Agar mendapatkan kontak permukaan yang lebih baik sisi dingin dan panas modul 
thermoelektric dioleskan termal pasta. Untuk mempercepat pembuangan kalor modul thermoelektric pada bagian heatsink dipasang wind tunnel dengan menggunakan blower yang bisa divariasikan kecepatan udaranya. Untuk mengetahui panas yang mengalir dari sisi panas modul thermoelektric ke heatsink pada bagian ujung heatsink dipasang termokopel keempat. Data temperatur dari masing-masing termokopel dapat dilihat dari perangkat komputer setelah dihubungkan dengan data logger. Modul thermoelektric dan blower masing-masing dihubungkan menggunakan power supply. Menghidupkan power supply dan siap untuk melakukan pengambilan data.

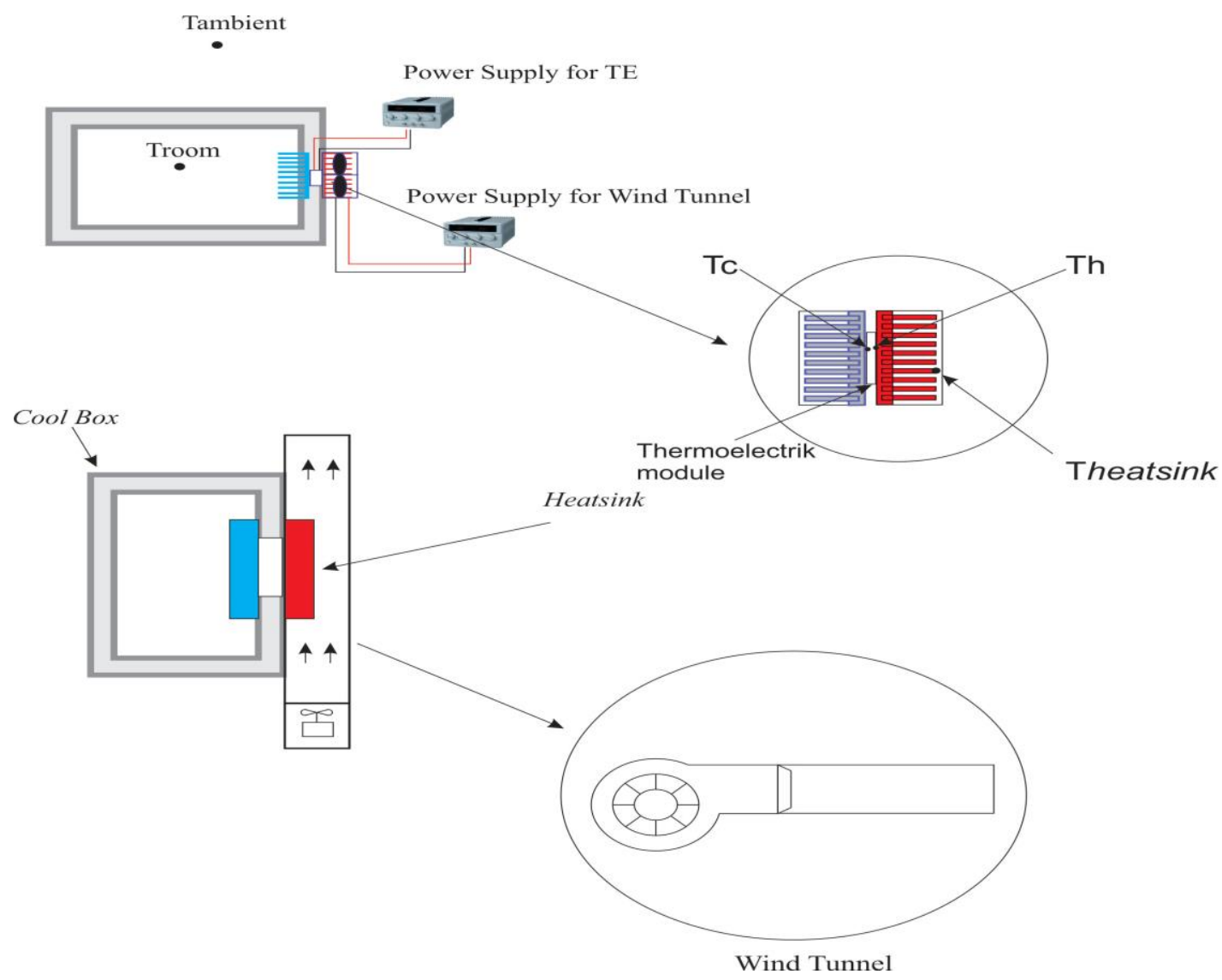

Gambar 2: Skema instalasi penelitian

Bila dua atau lebih lampu (tahanan R1 dan R2 dsb) dirangkaikan di dalam sirkuit, hanya ada jalur dimana arus dapat mengalir. Tipe penyambungan seperti ini, disebut rangkaian seri. Rangkaian seri dengan 6 modul TEC yang disusun secara menyebar. Adapun konektivitas kabelnya sebagai berikut: kabel merah (+) TEC 1 dihubungkan dengan kabel hitam (-) TEC 6, kabel hitam (-) TEC 1 dihubungkan kabel merah (+) TEC berikutnya. Rangkaian seri ditunjukkan pada Gambar 3.

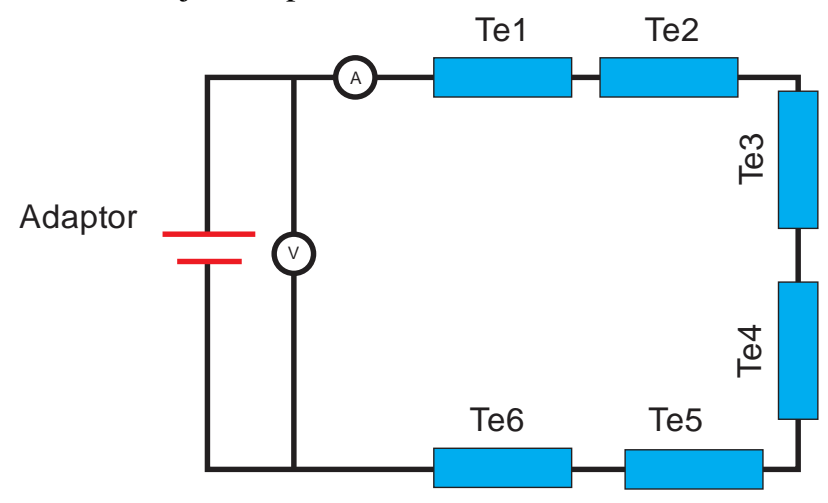

Gambar 3: Rangkaian seri 
Rangkaian paralel, dua atau lebih tahanan (R1, R2, dst) dihubungkan di dalam sirkuit, salah satu dari setiap ujung resistance dihubungkan ke bagian yang bertegangan tinggi (positif) dari sirkuit dan ujung lainnya dihubungkan ke bagian yang lebih rendah (negatif). Rangkaian paralel ditunjukkan pada Gambar 4.

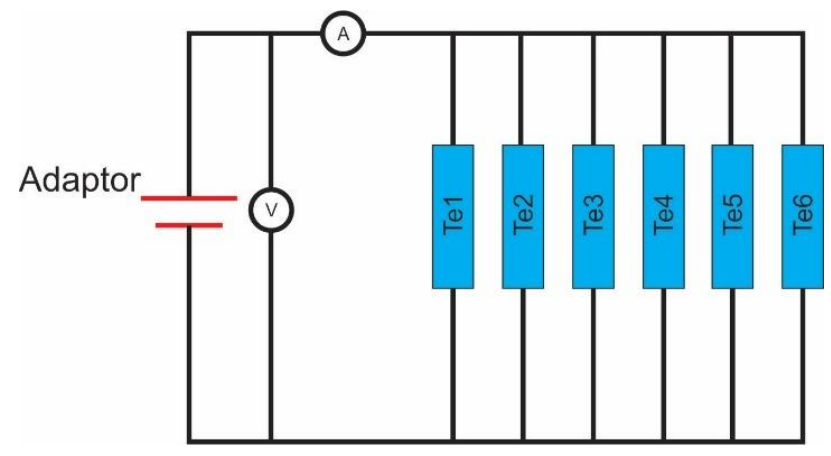

Gambar 4: Rangkaian Paralel

Koordinat pengambilan data temperatur ditunjukkan pada gambar 5. Dimana T1 adalah temperatur ujung heatsink, T2 temperatur sisi panas thermoelektric, T3 Temperatur sisi dingin thermoelektric, T4 temperatur ruang kotak pendingin dan T5 Temperatur ambient. Koordinat pengambilan data ditunjukkan pada Gambar 5.

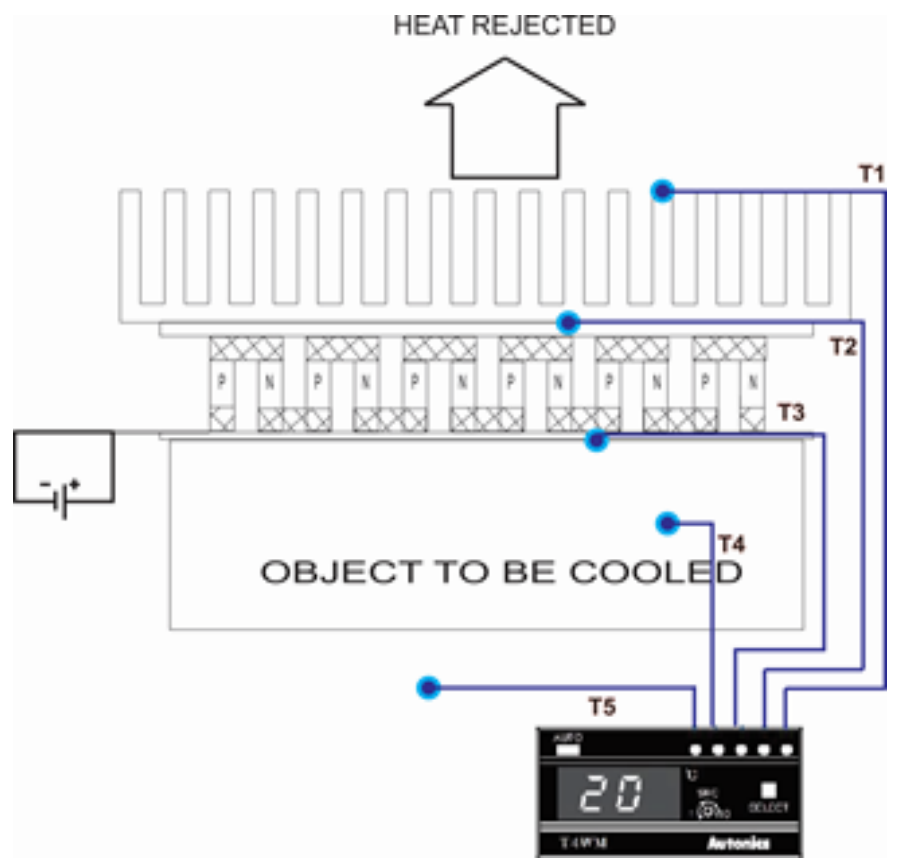

Gambar 5: Kordinat pengambilan data

\subsection{Data Reduksi}

Penelitian ini menggunakan data reduksi untuk menganalisis hasil eksperimen. Performa thermoelektric tergantung dari bahan semi konduktor yang digunakan. Terdapat tiga sifat bahan thermoelectric yaitu koefisien seebeck seperti pada persamaan 1 dan 2 [6], konduktivitas termal seperti pada persamaan 3 dan 4 [6] dan tahanan elektrik seperti pada persamaan 5 dan 6 [6]

Koefisien seebeck

$\alpha=2 . \alpha_{m} . N$

Koefisien Seebeck elemen

$\alpha_{m}=\alpha_{0}+\alpha_{1} T_{a v e}+\alpha_{2} T_{a v e}{ }^{2}$ 
Dimana :

$$
\begin{aligned}
& \alpha_{m}=\text { Koefisien seebeck elemen }[\mathrm{V} / \mathrm{K}] \\
& \alpha_{0}=2.2224 \times 10^{-5} \\
& \alpha_{1}=9.306 \times 10^{-7} \\
& \alpha_{2}=-9.905 \times 10^{-10} \\
& T_{\text {ave }}=(\mathrm{Tc}+\mathrm{Th}) / 2
\end{aligned}
$$

Konduktivitas termal

$$
K=2 . K_{m} \cdot N \cdot G
$$

Dimana :

$$
\begin{array}{ll}
K_{m} & =\text { Konduktivitas termal elemen }(\mathrm{W} / \mathrm{cmK}) \\
\mathrm{G} & =\text { Faktor Geometri }
\end{array}
$$

Dalam penelitian ini, faktor geometri di dapatkan melalui pengukuran tegangan dan arus listrik TEC yang kemudian dengan menggunakan AZTEC software;Version 4.0, laird Technologies, didapatkan faktor geometri yang sesuai dengan TEC1 12706 yang digunakan adalah 0,121.

Konduktifitas termal elemen

$$
K_{m}=K_{0}+K_{1} T_{a v e}+K_{2} T_{a v e}^{2}
$$

Dimana ;

$K_{m} \quad=$ Konduktivitas termal elemen $[\mathrm{W} / \mathrm{cmK}]$

$K_{0} \quad=6.2605 \times 10^{-2}$

$K_{1}=-2.777 \times 10^{-4}$

$K_{2}=4.131 \times 10^{-7}$

$T_{\text {ave }}=(\mathrm{Tc}+\mathrm{Th}) / 2$

Tahanan Elektrik

$$
R=\frac{2 \cdot \rho \cdot N}{G}
$$

Tahanan Elektrik elemen

$$
\rho_{m}=\rho_{0}+\rho_{1} T_{a v e}+\rho_{2} T_{\text {ave }}^{2}
$$

Dimana ;

$$
\begin{array}{ll}
\rho_{0} & =5,112 \times 10^{-5} \\
\rho_{1} & =1,634 \times 10^{-6} \\
\rho_{2} & =6,279 \times 10^{-9} \\
T_{\text {ave }} & =(\mathrm{Tc}+\mathrm{Th}) / 2
\end{array}
$$

Terjadinya perpindahan panas dari dalam cool box dan panas yang masuk ke dalam cool box merupakan beban panas yang harus dipindahkan dari dalam ruangan cool box ke lingkungan seperti pada persamaan 7 dan 8 [6] 
Kalor yang dilepaskan pada sisi panas TEC

$\dot{q}_{c}=2 N\left[\alpha_{m} \cdot I \cdot T_{c}-K_{m} \cdot \Delta T+\left(\frac{I^{2} \rho}{2 G}\right)\right]$

Kalor yang diserap pada sisi dingin

$\dot{q}_{h}=2 N\left[\alpha_{m} \cdot I \cdot T_{h}-K_{m} \cdot \Delta T+\left(\frac{I^{2} \rho}{2 G}\right)\right]$

Figure of merit, (Z) merupakan parameter gabungan dari tiga jenis sifat pada thermoelectric dan sangat berpengaruh besar terhadap pendinginan yang terjadi. Pendinginan thermoelectric sangat dipengaruhi oleh nilai $Z$. semakin besar nilai $Z$ maka nilai $\Delta T$ semakin tinggi pula. Nilai $Z$ dapat menunjukkan kualitas dari elemen thermoelectric seperti pada persamaan 9 [6]

$$
Z=\frac{\alpha_{m}{ }^{2}}{\rho \cdot K_{m}}
$$

COP adalah indikator kinerja dari kotak pendingin yaitu disebut dengan coefficient of performance. Unjuk kerja dari kotak pendingin dapat dihitung dengan persamaan 10 [6]

$$
C O P=\frac{q_{c}}{P_{i n}}
$$

\section{HASIL DAN DISKUSI}

Hasil penelitian ini disajikan dalam bentuk grafik. Sebelum menampilkan hasil-hasil penelitian berupa jawaban dari pertanyaan ataupun tujuan penelitian, maka perlu disajikan terlebih dahulu prilaku temperatur seiring bertambahnya waktu pengamatan. Gambar 6 dan Gambar 7 menampilkan temperatur variabel bebas yang diperoleh dari eksperimen yaitu temperatur ruangan, temperatur sisi dingin thermoelektric, temperatur sisi panas thermoelektric, temperatur heatsink, dan temperatur lingkungan. 
Rangkaian seri

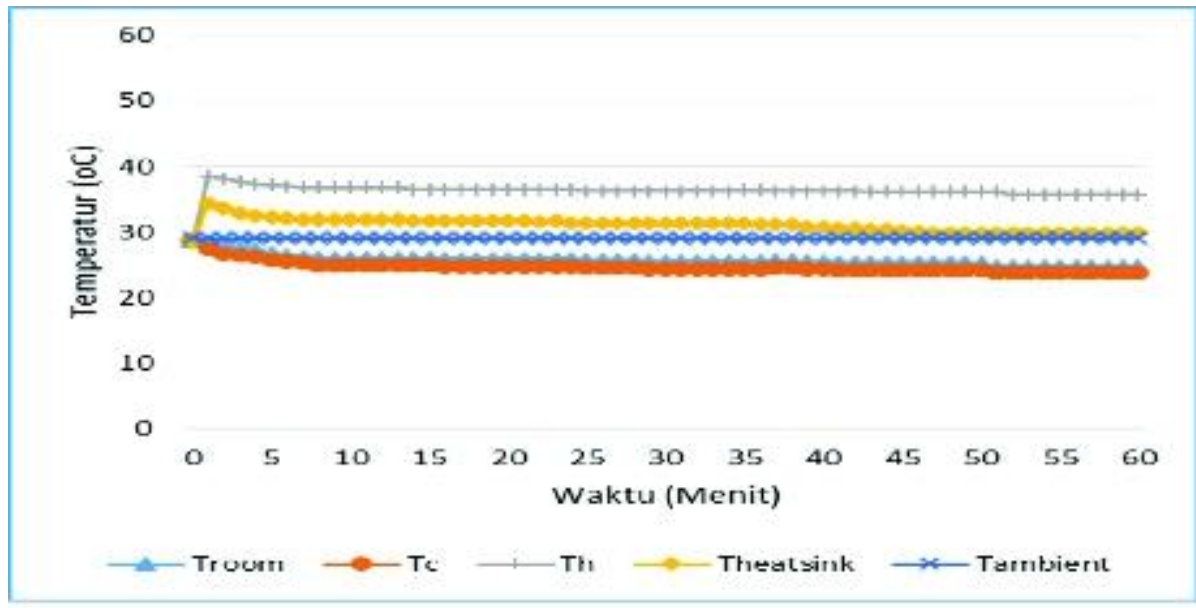

d

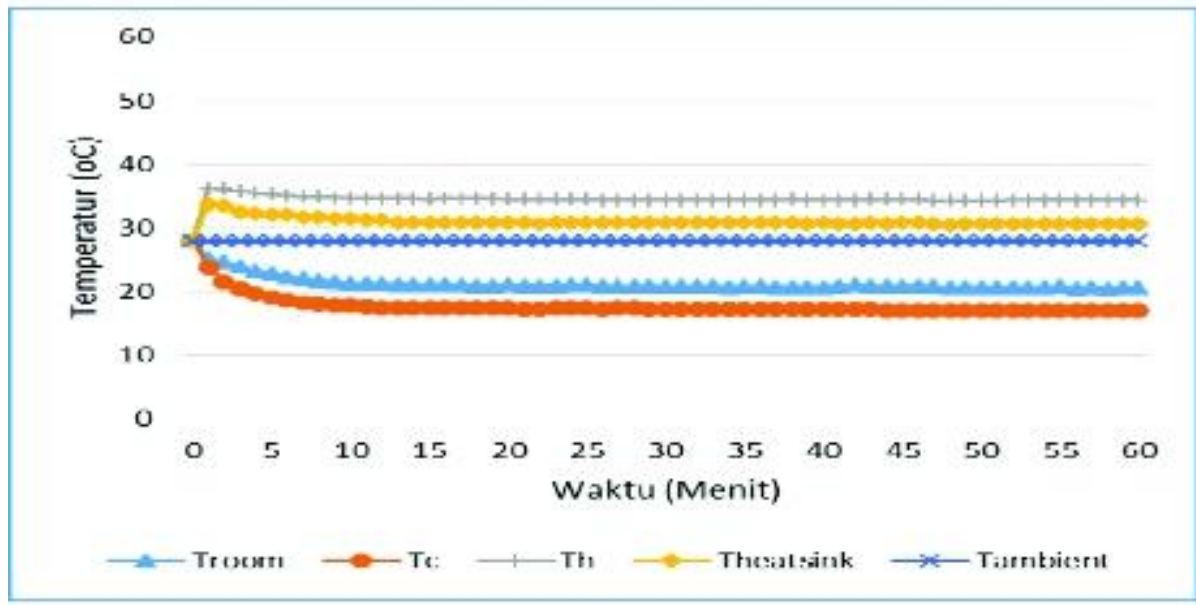

b

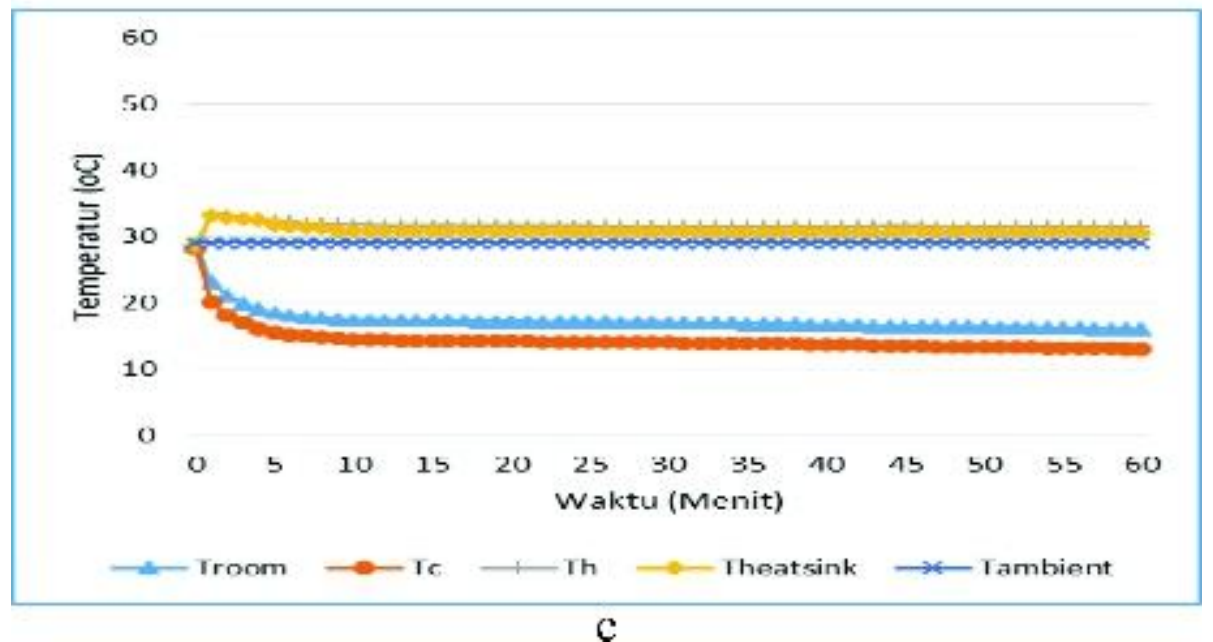

Gambar 6: Tren temperatur terhadap waktu ; (a) Kecepatan udara 4,2 m/s, (b) Kecepatan Udara 6 m/s dan (c) Kecepatan udara $9,8 \mathrm{~m} / \mathrm{s}$. 
Rangkaian paralel

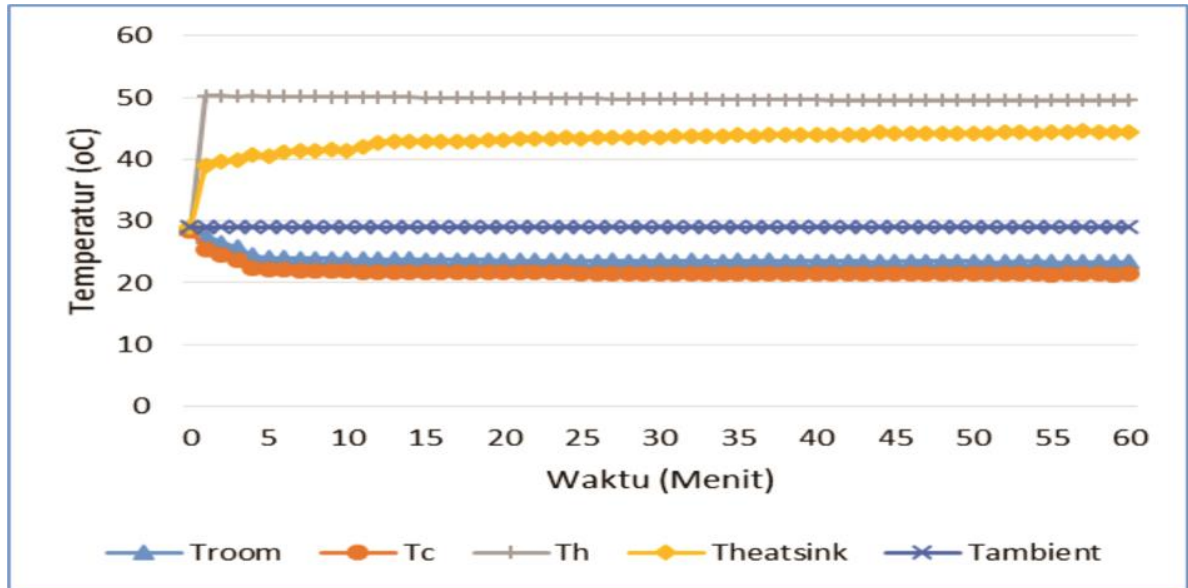

a

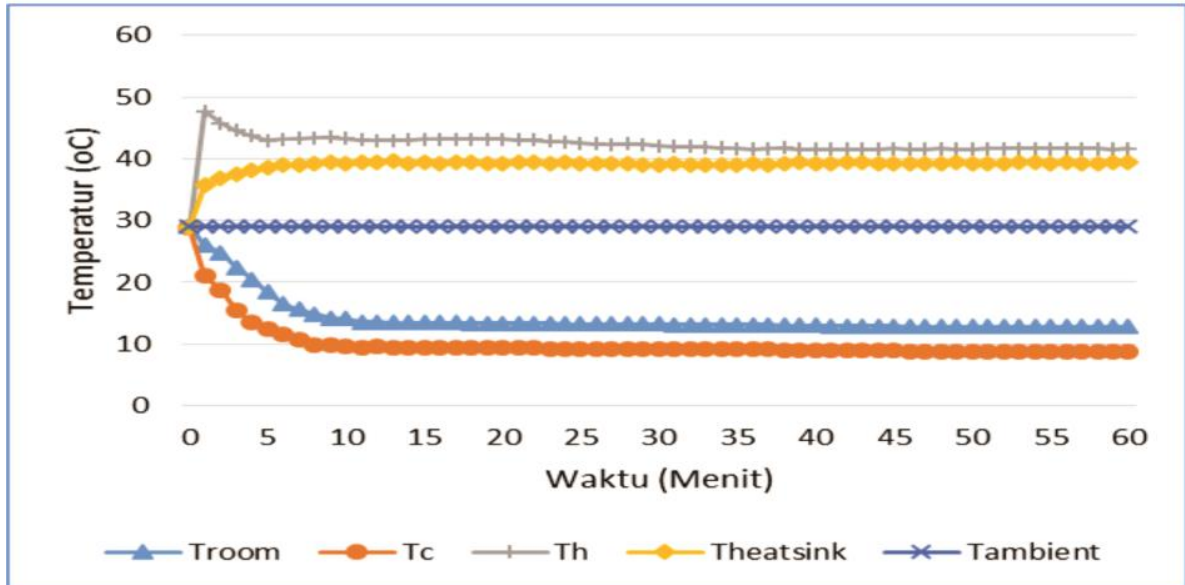

b

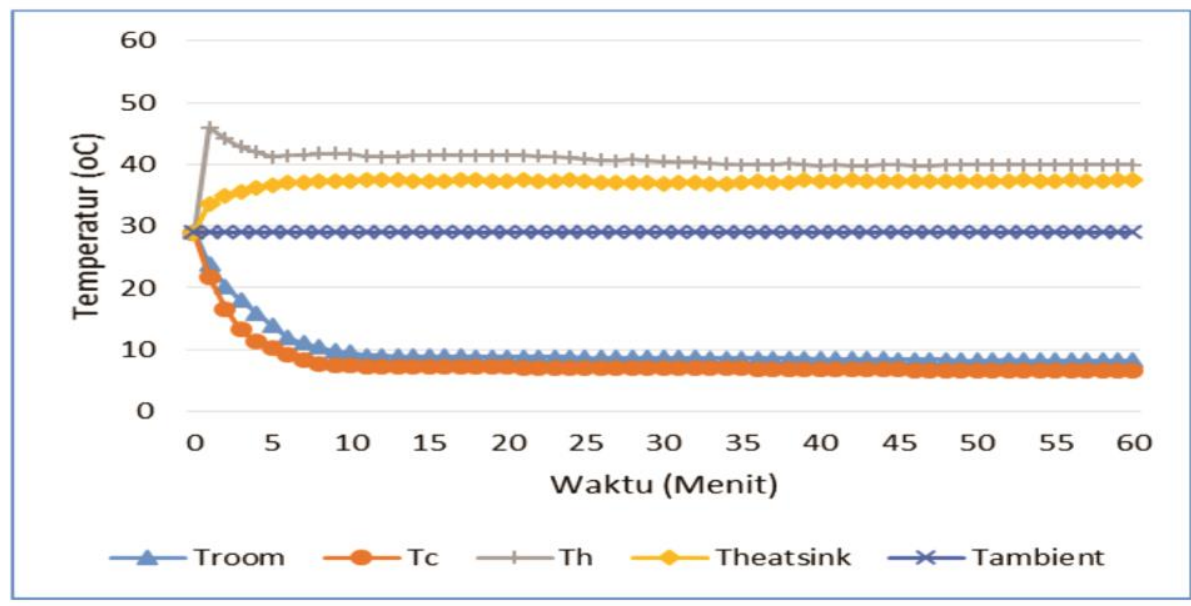

C

Gambar 7: Tren Temperatur terhadap Waktu ; (a) Kecepatan Udara 4,2 m/s, (b) Kecepatan Udara 6 m/s dan (c) Kecepatan Udara $9,8 \mathrm{~m} / \mathrm{s}$. 
Gambar 6 dan Gambar 7 menunjukkan bahwa temperatur ruangan, temperatur sisi dingin modul thermoelektric, temperatur sisi panas modul thermoelektric dan temperatur heatsink masing-masing menurun seiring bertambahnya waktu pengamatan atau waktu kerja kotak pendingin. Penurunan paling signifikan adalah dari nol hingga menit ke 9. Setelah itu temperatur tetap menurun tetapi sangat kecil penurunannya dan bahkan hampir konstan. Bila temperatur-temperatur konstan maka kondisi mencapai steady. Menurunnya suhu ruangan disebabkan panas didalam ruangan kotak pendingin diserap oleh heatsink dalam yang kemudian diteruskan ke sisi dingin modul thermoelektric. Karena ruangan tertutup dan dinding kotak pendingin menggunakan material isolator panas seperti styrofoam maka makin lama suhu dalam ruangan makin turun. Tren suhu yang demikian juga ditemukan oleh para peneliti sebelumnya Fenomena seperti ini terjadi karena thermoelektric tidak seketika menjadi dingin, artinya memerlukan waktu unutk mencapai temperatur minimum yang mampu diraihnya.

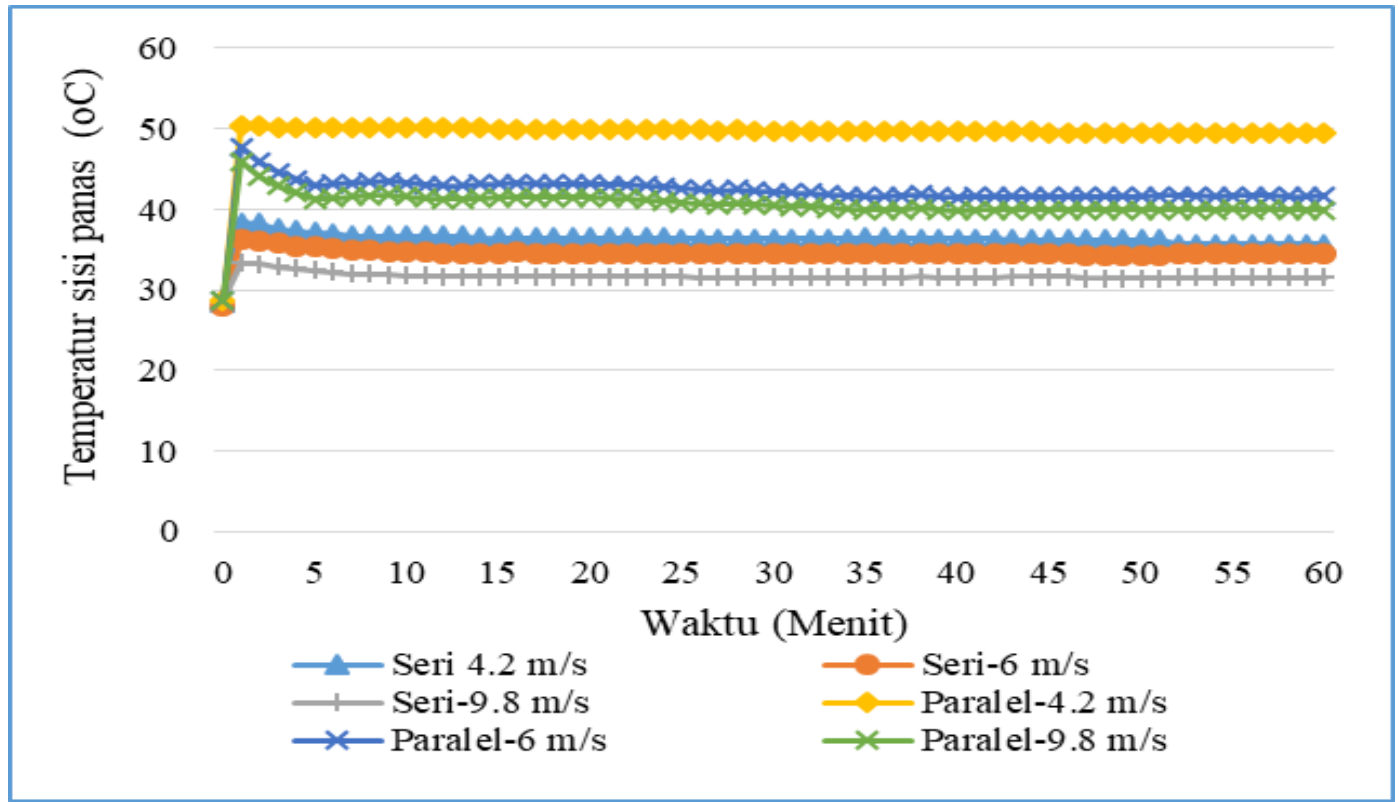

Gambar 8: Hubungan antara temperatur sisi panas thermoelectric terhadap waktu

Selain rangkaian thermoelektric, komponen pembuang panas juga memiliki pengaruh yang besar terhadap nilai kalor sisi panas thermoelektric (Th). Gambar 8 menunjukkan bahwa rangkaian paralel dengan kecepatan udara 4,2 m/s memiliki kalor sisi panas paling besar. Kalor sisi panas yang dicapai sebesar 49,5 ${ }^{\circ} \mathrm{C}$. jika dibandingkan dengan rangkaian paralel dengan kecepatan udara $9,8 \mathrm{~m} / \mathrm{s}$ kalor sisi panasnya lebih rendah sebesar $40^{\circ} \mathrm{C}$. Hal ini menunjukkan bahwa semakin tinggi kecepatan udara dapat membuang panas lebih cepat. Rangkaian paralel memiliki kalor sisi panas lebih besar dibandingkan rangkaian seri. Rangkaian paralel dengan kecepatan udara $9,8 \mathrm{~m} / \mathrm{s}$ kalor sisi panas yang dicapai sebesar $40{ }^{\circ} \mathrm{C}$ sedangkan untuk rangkaian seri dengan kecepatan udara $9,8 \mathrm{~m} / \mathrm{s}$ kalor sisi panas yang dicapai sebesar $31,5{ }^{\circ} \mathrm{C}$. Perubahan konfigurasi rangkaian memberikan pengaruh terhadap perubahan arus dan daya yang diberikan. Semakin besar daya yang diberikan (beban yang sama) maka nilai kalor pada sisi panas (Th) akan semakin besar. Dari grafik terlihat bahwa perubahan temperatur pada modul elemen peltier terlihat semakin tinggi daya yang diberikan maka akan semakin tinggi pula nilai dari temperatur sisi panasnya [13]. Hal ini mendukung pernyataan bahwa nilai kalor sisi panas merupakan jumlah dari nilai kalor yang diserap ditambah dengan daya input dari peltier. 


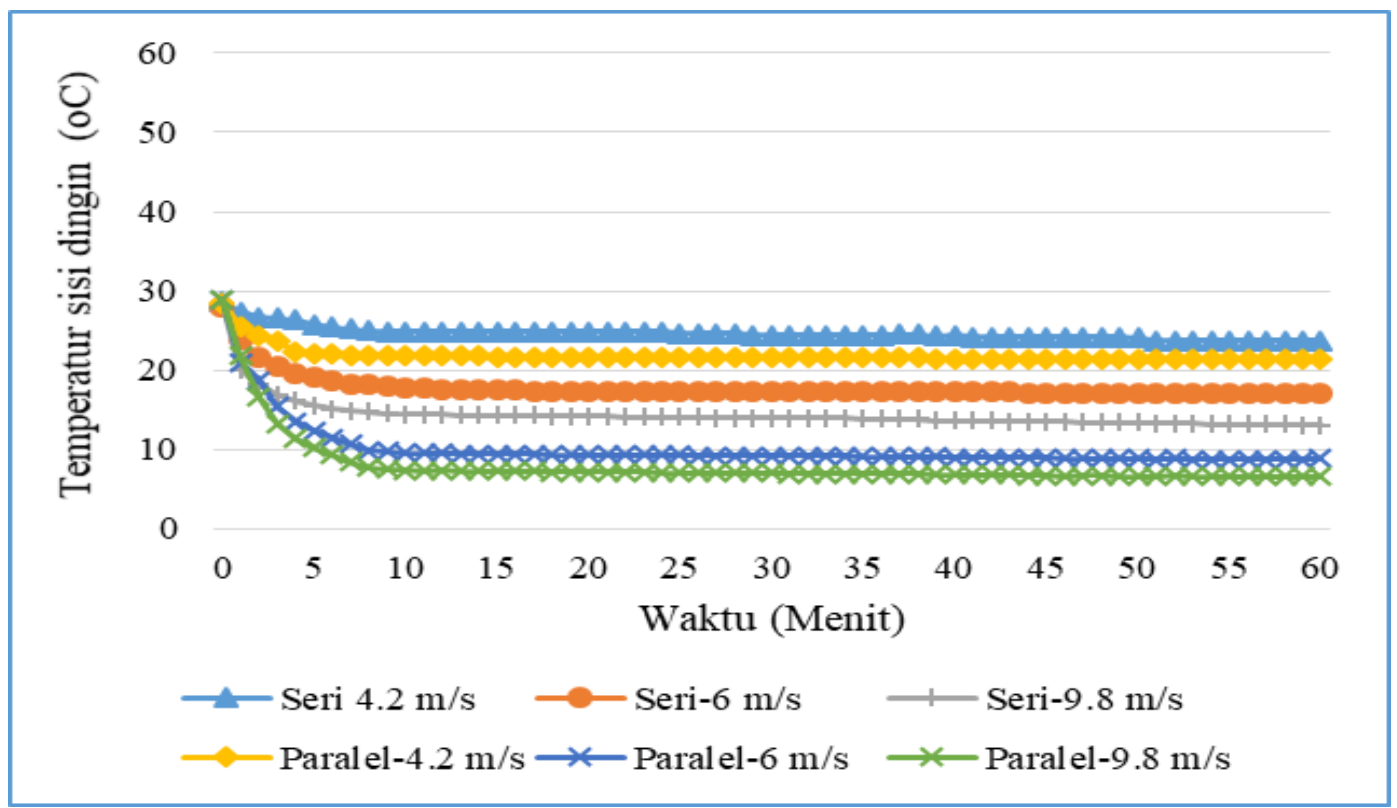

Gambar 9: Hubungan antara temperatur sisi dingin thermoelectric dengan waktu

Rangkaian thermoelektric memberikan pengaruh yang cukup signifikan terhadap temperatur sisi dingin thermoelektric. Dari Gambar 9 terlihat bahwa capaian suhu yang paling rendah dicapai rangkaian paralel dengan kecepatan udara $9,8 \mathrm{~m} / \mathrm{s}$. temperatur sisi dingin yang dapat dicapai sebesar $6,6^{\circ} \mathrm{C}$ sedangkan rangkaian seri dengan kecepatan udara $9,8 \mathrm{~m} / \mathrm{s}$ capaian temperatur sisi dinginnya mencapai $13{ }^{\circ} \mathrm{C}$. Capaian suhu sisi dingin tiap-tiap elemen peltier tergantung jumlah arus yang digunakan. Penelitian yang dilakukan menunjukkan arus listrik yang maksimal didapatkan suhu sisi dingin elemen peltier yang rendah pada jumlah TEC yang sama [14]. Penggunaan elemen peltier rangkaian paralel diperoleh capaian suhu yang rendah dibandingkan dengan rangkaian seri. Hal tersebut disebabkan banyaknya arus yang melalui elemen peltier. Banyaknya arus listrik yang melalui elemen peltier rangkaian seri lebih sedikit sehingga panas yang dipindahkan juga akan semakin kecil. Pada rangkaian paralel masing-masing modul mendapatkan arus langsung dari sumber sehingga arus listrik yang ditimbulkan sangat besar [12].

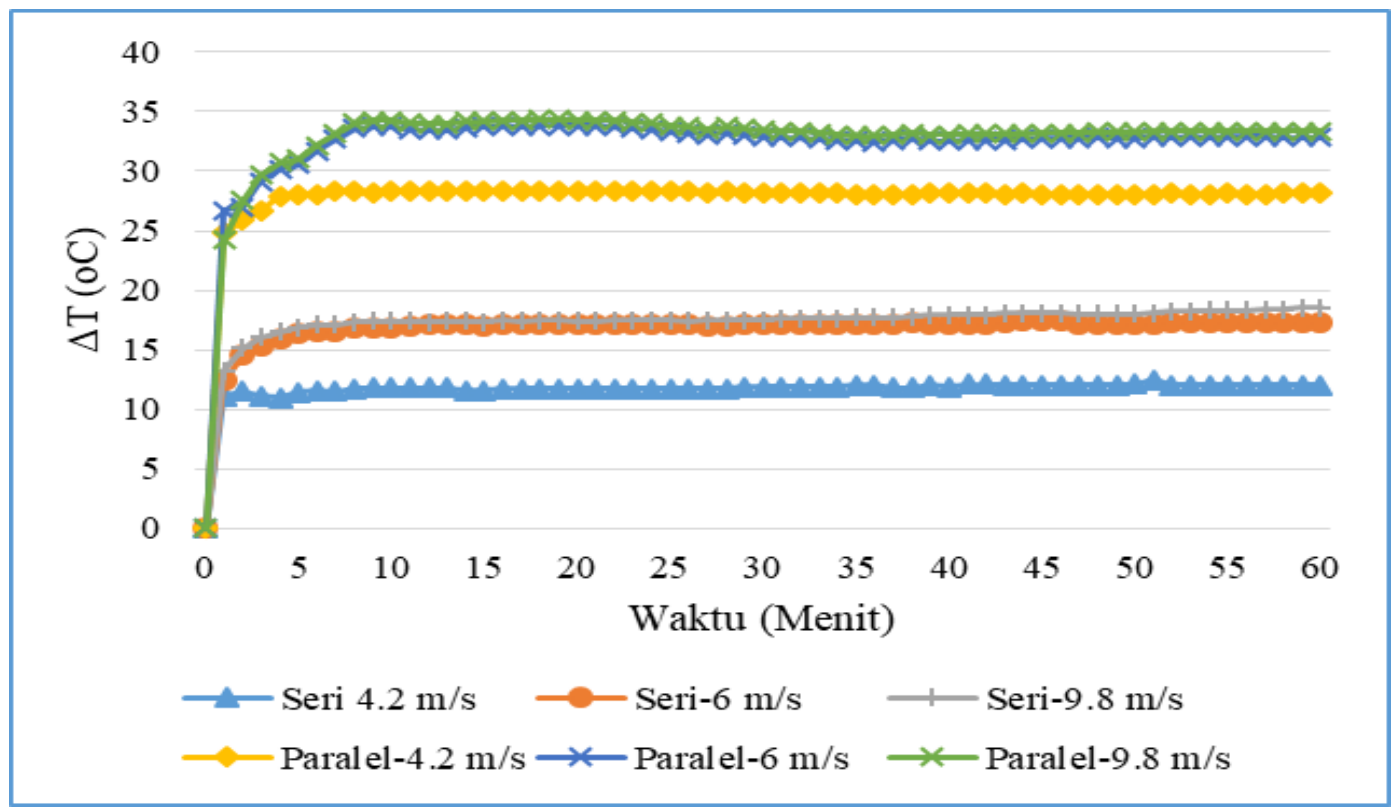

Gambar 10: Hubungan antara perbedaan temperatur terhadap waktu

Gambar 10 memperlihatkan hubungan antara beda temperatur dengan rangkaian thermoelektric. Beda temperatur $(\Delta \mathrm{T})$ terbagi menjadi dua kelompok berdasarkan rangkaian thermoelektric, dimana tampak bahwa pada rangkaian seri menghasilkan $\Delta \mathrm{T}$ yang lebih rendah dibandingkan dengan rangkaian paralel. Pada 
rangkaian yang sama, beda temperatur sisi dingin dan sisi panas thermoelektric juga mengalami perubahan. Kecepatan udara $4,2 \mathrm{~m} / \mathrm{s}$ menghasilkan $\Delta \mathrm{T}$ yang lebih rendah dibandingkan dengan kecepatan udara 9,8 m/s. Hal ini menunjukkan bahwa perubahan laju aliran udara pendingin pada rangkaian thermoelektric yang sama secara signifikan menghasilkan perubahan $\Delta \mathrm{T}$. Beda temperatur merupakan selisih antara temperatur sisi panas (Th) dengan temperatur sisi dingin (Tc). Rangkaian thermoelektric memberikan pengaruh yang cukup signifikan terhadap beda temperatur. Beda temperatur yang paling tinggi ditunjukkan rangkaian paralel dengan kecepatan udara $9,8 \mathrm{~m} / \mathrm{s}$ yaitu $33,4{ }^{\circ} \mathrm{C}$ dan beda temperatur paling rendah ditunjukkan rangkaian seri dengan kecepatan udara $4,2 \mathrm{~m} / \mathrm{s}$ yaitu $12{ }^{\circ} \mathrm{C}$. Hal ini menunjukkan selisih antara temperatur sisi panas thermoelektric dengan temperatur sisi dingin thermoelektric berbeda-beda. Dari grafik bahwa dengan merubah rangkaian thermoelektric dan menambah kecepatan udara pembuangan kalor maka beda temperatur $(\Delta \mathrm{T})$ yang dihasilkan semakin besar. Hal ini dikarenakan kecepatan udara yang lebih tinggi akan lebih membantu proses konveksi perpindahan panas dari sisi panas thermoelektric ke heatsink dan ke lingkungan. Sejalan penelitian yang dilakukan dimana peningkatan laju aliran fluida pada heatsink berdampak pada peningkatan laju lepasan kalor pada sisi panas dan arus listrik thermoelektric yang diikuti penurunan temperatur sisi dingin thermoelektric [15].

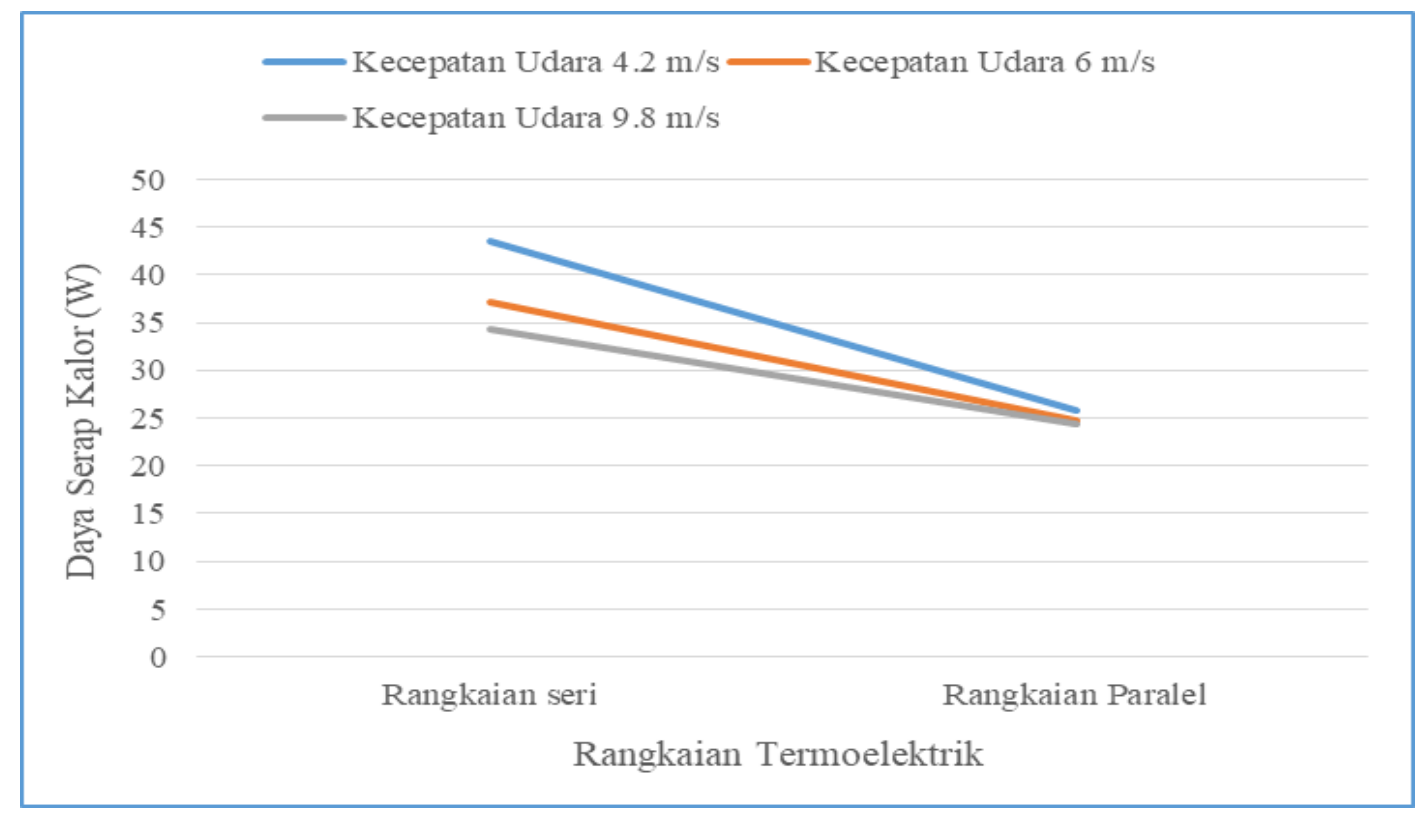

Gambar 11: Pengaruh rangkaian thermoelektric terhadap daya serap kalor

Daya serap kalor TEC (Qc) ditunjukkan pada Gambar 11. Tampak bahwa daya serap kalor terbagi dua kelompok berdasarkan rangkaian thermoelektric. Daya serap kalor pada rangkaian seri lebih tinggi dibandingkan dengan daya serap kalor rangkaian paralel. Meski perbedaan daya serap kalor pada rangkaian yang sama tidak begitu besar, namun daya serap kalor tertinggi terjadi pada rangkaian seri dengan kecepatan udara 4,2 m/s dengan rata-rata sebesar 43,52 W. Hal tersebut disebabkan karena nilai dari daya serap kalor (Qc) berbanding lurus dengan nilai arus yang ditimbulkan. Semakin besar tegangan listrik maka arus yang ditimbulkan juga semakin besar, semakin besar hambatan listrik maka arus yang ditimbulkan juga semakin kecil. Nilai daya serap kalor (Qc) juga berbanding lurus dengan capaian temperatur sisi dingin thermoelektric. Rangkaian seri capaian temperatur sisi dingin thermoelektric dengan arus yang ditimbulkan lebih optimal sehingga daya serap kalornya lebih tinggi. Koneksitas rangkaian paralel semua percabangan dilalui arus listrik langsung dari sumber sehinnga daya serap kalornya sangat besar tetapi tidak sebanding dengan daya input yang diberikan [12]. 


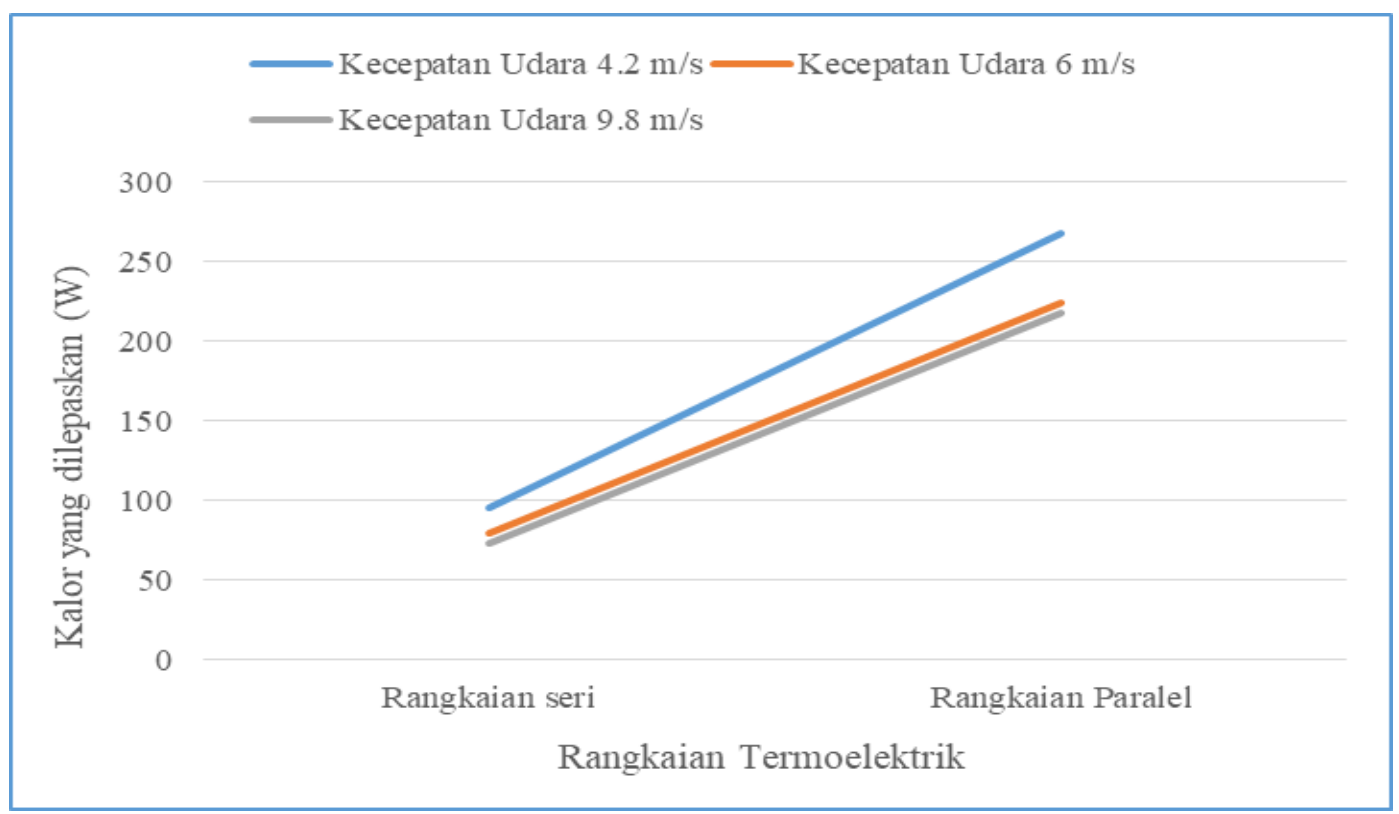

Gambar 12: Pengaruh rangkaian thermoelektric terhadap kalor yang dilepaskan

Berbeda dengan daya serap kalor (Qc), kalor yang dilepaskan (Qh) mengalami perubahan seiring dengan perubahan rangkaian termolektrik dan kecepatan udaranya, seperti yang tampak pada Gambar 12 dimana kalor yang dilepaskan (Qh) tertinggi dicapai pada rangkaian paralel pada kecepatan udara 4,2 m/s. semakin besar nilai arus yang disuplai maka perbedaan temperatur kedua sisi thermoelektric semakin meningkat. Pada konfigurasi ini temperatur ruang kotak pendingin yang dihasilkan cukup tinggi $23,4{ }^{\circ} \mathrm{C}$. Hal ini disebabkan oleh sisi panas pada thermoelektric yang merupakan sisi yang melepas kalor tidak dapat melepas kalor dengan cepat mengakibatkan sisi dingin thermoelektric mengalami peningkatan. Rata-rata temperatur sisi panas $49,5^{\circ} \mathrm{C}$. dan rata-rata kalor yang dilepaskan sebesar $267,76 \mathrm{~W}$. untuk mempercepat pelepasan kalor dapat dilakukan dengan menambah kecepatan udara unit pembuang panasnya.

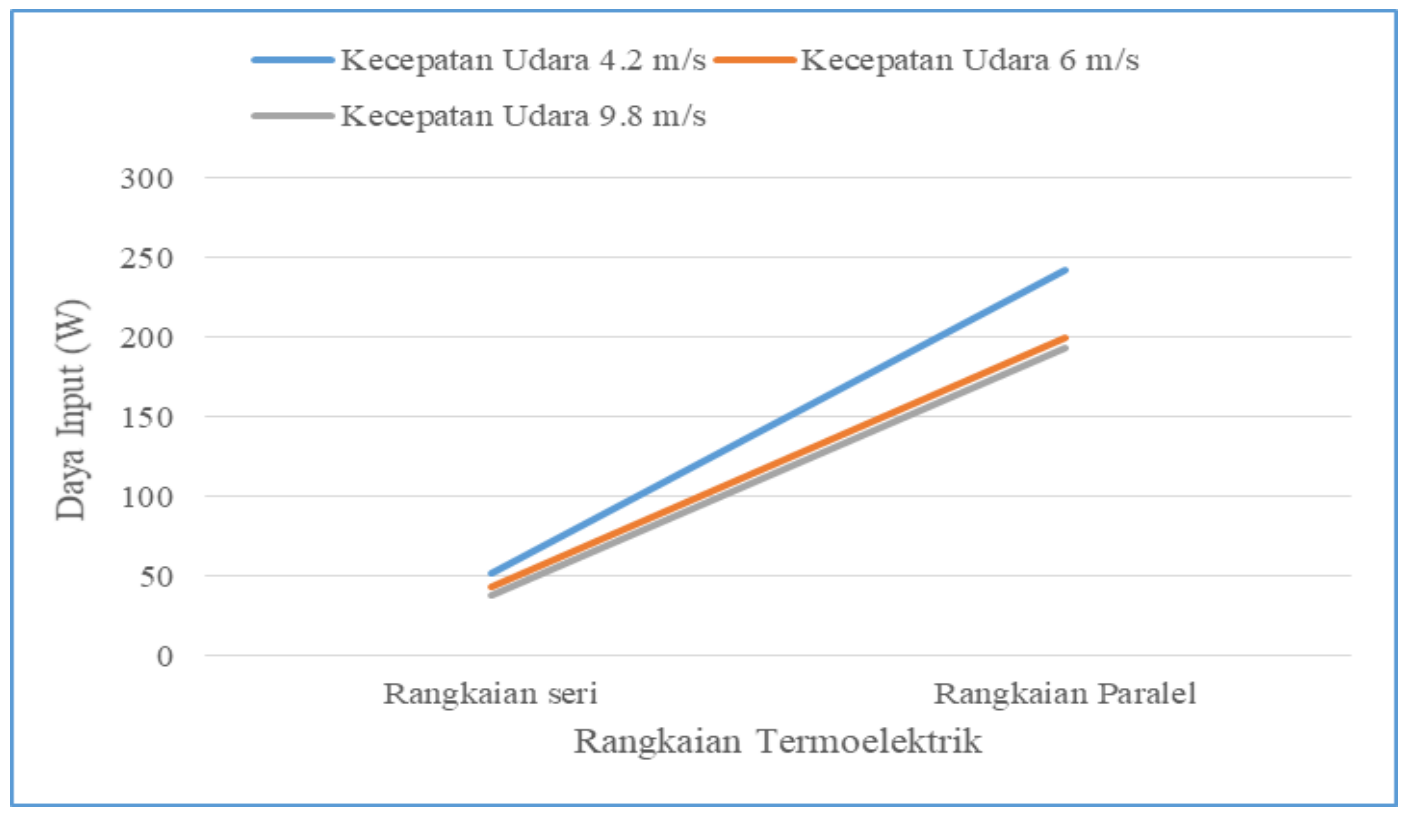

Gambar 13: Pengaruh rangkaian thermoelektric terhadap daya input

Hubungan antara daya input dengan rangkaian thermoelektric diperlihatkan Gambar 13. Rangkaian thermoelektric nmemberikan pengaruh yang sangat signifikan terhadap daya input (Pin). Daya input paling tinggi ditunjukkan rangkaian paralel kecepatan udara 4,2 $\mathrm{m} / \mathrm{s}$ sebesar 241,96 W. Hal ini disebabkan daya input berbanding lurus dengan arus ditimbulkan. Arus yang 
ditimbulkan rangkaian paralel lebih besar dimana masing-masing modul thermoelektric mendapatkan arus langsung dari sumber berbeda dengan rangkaian seri dimana hanya ada satu jalan yang dilalui, arus yang mengalir secara berurutan. Dengan demikian salah satu cara untuk mengurangi kebutuhan arus pada thermoelektric adalah dengan menggunakan elemen peltier dengan perakitan kelistrikan seri. Perakitan kelistrikan secara paralel elemen peltier agar diperoleh perbedaan suhu yang tinggi antara kedua sisi elemen peltier, sehingga kalor yang dilepaskan semakin besar. Penyusunan kelistrikan secara seri agar diperoleh jumlah arus listrik yang melalui elemen peltier lebih optimal [16].

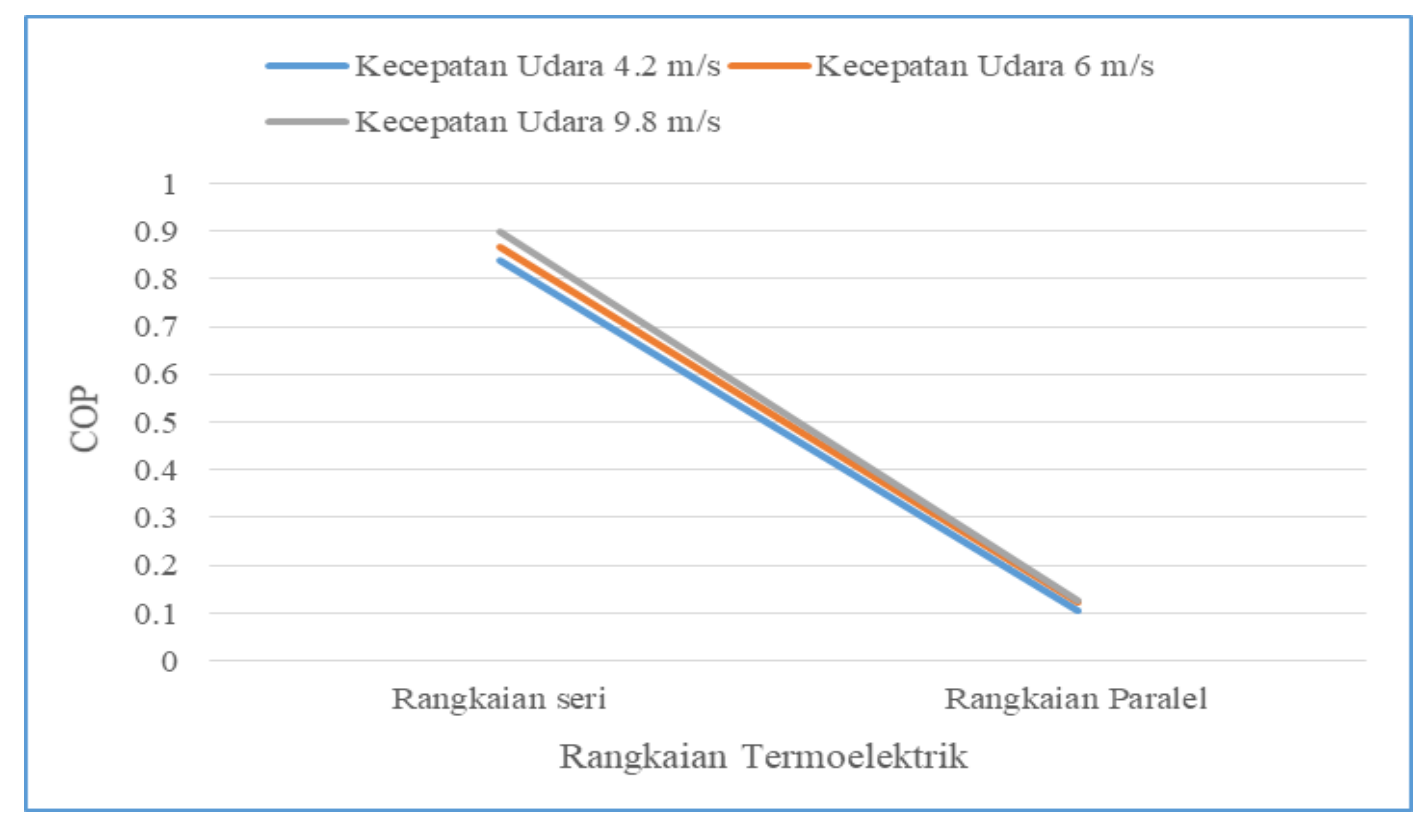

Gambar 14: Pengaruh rangkaian thermoelektric terhadap Coefficient of Performance

Coefficient of performance (COP) sistem ditunjukkan pada Gambar 14 dimana rangkaian seri memiliki COP yang lebih tinggi dibandingkan dengan rangkaian paralel. Rangkaian seri dengan kecepatan udara $9,8 \mathrm{~m} / \mathrm{s}$ nilai COP mencapai 0,89 sedangkan pada rangkaian paralel dengan kecepatan udara $9,8 \mathrm{~m} / \mathrm{s}$ nilai COP mencapai 0,12 . Pada kedua konfigurasi rangkaian memiliki tren yang sama, dimana COP akan meningkat seiring dengan penambahan kecepatan udara pembuang kalor. Hal ini disebabkan pada rangkaian seri arus listrik yang digunakan lebih optimal sehingga daya input yang diberikan sebanding dengan daya serap kalornya sehingga kinerjanya lebih tinggi. Pada rangkaian paralel arus listrik yang ditimbulkan sangat besar sehingga daya serap kalornya sangat tinggi tetapi tidak sebanding dengan daya input yang juga sangat besar sehingga kinerja modul thermoelektric lebih rendah. Penurunan COP merupakan dampak dari perubahan efek thomson yang diikuti oleh penurunan efek fourier dan joule heating pada sisi dingin TEC. Hal ini menunjukkan bahwa meskipun peningkatan laju aliran pendingin akan meningkatkan efek pelepasan kalor ruangan kotak pendingin, namun disisi lain akan berdampak pada peningkatan daya input sistem.

\section{KESIMPULAN}

Dari penelitian yang telah dilakukan dapat disimpulkan bahwa rangkaian thermoelektric dan kecepatan udara wind tunnel sangat mempengaruhi kinerja dari kotak pendingin. Kinerja yang lebih tinggi diperoleh pada kotak pendingin yang secara listrik koneksitas thermoelektric dirangkai seri dengan kecepatan udara wind tunnel $9,8 \mathrm{~m} / \mathrm{s}$ dimana daya serap kalor $(\mathrm{Qc})$ yang dihasilkan $34,265 \mathrm{~W}$, beda temperatur $(\Delta \mathrm{T})$ mencapai $18,5{ }^{\circ} \mathrm{C}$ dan daya input (Pin) sebesar $38,14 \mathrm{~W}$ sehingga COP menjadi 0,89 . Sedangkan pada rangkaian paralel dengan kecepatan udara $9,8 \mathrm{~m} / \mathrm{s}$ dimana daya serap kalor $24,442 \mathrm{~W}$, beda temperatur $(\Delta \mathrm{T})$ mencapai $33,4^{\circ} \mathrm{C}$ dan daya input (Pin) sebesar 193,08 W sehingga COP menjadi 0,12. Dengan menggunakan rangkaian seri thermoelektric pada kotak pendingin dapat meningkatkan kinerja thermoelektric dibandingkan dengan rangkaian paralel. 


\section{DAFTAR PUSTAKA}

[1] R. D, G. M, D. SCHOLLMEYER, S. . HELLMANN, R and WALDVOGEL, "Methyl-Substituted aCyclodextrin asAffinity Material for Storage, Separation, and Detection of Trichlorofluoromethane," Glob. Challenges, vol. 2, No 8., p. 1800057, 2018.

[2] S. SM, K. GNANASEKARAN, and S. J. SAMUEL, "Performance study on thermoelectric cooling and heating system with cascaded and integrated approach", Int. J. Chem. Stud, vol. 6, no. 1, pp. 1348-1354, 2018.

[3] A. K. CHOUDHARY and N. KUMAR, "International Journal Of Engineering Sciences \& Research Technology Security", Int. J. Eng. Sci. Res. Technol., vol. 6, no. 9, p. 5, 2017.

[4] A. K. MAINIL, A. AZIZ, and M. AKMAL, "Portable Thermoelectric Cooler Box Performance with Variation of Input Power and Cooling Load," Aceh Int. J. Sci. Technol., vol. 7, no. 2, pp. 85-92, 2018.

[5] M. MIRMANTO, S. SYAHRUL, and Y. WIRDAN, "Experimental performances of a thermoelectric cooler box with thermoelectric position variations," Eng. Sci. Technol. an Int. J., vol. 22, no. 1, pp. 177-184, 2019.

[6] M. MIRMANTO, I. BAGUS ALIT, and Y. ANGGANI, "Unjuk kerja kotak pendingin peltier dengan unit pembuang panas heat sink fin-fan dan single fan heat pipe",Jurnal Rekayasa Mesin, vol.1, n. 2, pp. 1-8, 2019.

[7] A. AZIZ, J. SUBROTO, and V. SILPANA, "Aplikasi modul pendingin thermoelektric sebagai media pendingin kotak minuman" Technology, vol. 10 no. 1, pp. 1-7, 2017.

[8] K. ANWAR and M. B. ANGGARA, "Pengaruh laju aliran fluida liquid-cooled heat sink terhadap unjuk kerja sistim pendingin thermoelektric", vol. 8 no. 2, pp. 759-767, 2017.

[9] M. YUSFI, F. GANDI, and H. S. PALKA, "Analisis Pemamfaatan Dua Elemen Peltier Pada Pengontrolan Temperatur Air," Spektra- J. Fis. dan Apl., vol. 2, no. April, pp. 9-14, 2017.

[10] T. N. WIDIANTO and A. R. HAKIM, "Performansi Pendingin Thermoelektric Alat Transportasi Ikan Segar pada Berbagai Tegangan (Thermoelectric Performance of Refrigerated Fish Container at Various Voltages)," Agritech, vol. 36, no. 4, pp. 485, 2017.

[11] T. NUGROHO and C. MAHENDRA, "Performance of Arrangement and Number the Peltier Elements on Refrigerated Fish Container TEC", Jurnal Pascapanen dan Bioteknologi Kelautan dan Perikanan, Vol. 14, no. 1, pp. 75-84, 2019.

[12] M. AKMAL and A. AZIZ, "Pengaruh jumlah Cascade daninput daya terhadap temperatur thermoelectric cooling box portable," Jom FTEKNIK, vol. 1, no. 2, pp. 1-4, 2014.

[13] B. K. RAKESH, A. SHAYAN, M. S. M. N, M. MOHAN, and V. KARTHIK, "Study Analysis and Fabrication of Thermoelectric Cooling System",International Journal of Scientific development and Research, vol. 1, no. 5, pp. 332-338, 2016.

[14] J. DELLY, M. HASBI, and I. FITRA ALKHOIRON, "Studi Penggunaan Modul Thermoelektric Sebagai Sistem Pendingin Portable," ENTHALPY - J. Ilm. Mhs. Tek. Mesin, vol. 1, no. 1, pp. 50-55, 2016.

[15] L. NULHAKIM, “Uji Unjuk Kerja Pendingin Ruangan Berbasis Thermoelectric Cooling,” Simetris J. Tek. Mesin, Elektro dan Ilmu Komput., vol. 8, no. 1, pp. 85-90, 2017.

[16] H. ANANTA, Y. A. PADANG, and M. MIRMANTO, "Unjuk kerja kulkas thermoelektric dengan rangkaian seri dan paralel pada beban air 1500 ml,” Din. Tek. Mesin, vol. 7, no. 2, pp. 80-86, 2017. 